\title{
Report on the Effect of Temperature and Ammonia Concentration on A515 Carbon Steel in Tank 241 AY 101 Simulant
}

\author{
D. P. Frye, J. B. Duncan, and R. W. Wyrwas \\ Washington River Protection Solutions LLC \\ Richland, WA 99352 \\ U.S. Department of Energy Contract DE-AC27-99Rt14047
}

$\mu \mu \mu_{1} \mid 2010^{8}$

\author{
EDT/ECN: DRF UC: \\ Cost Center: 2EK00 Charge Code: \\ B\&R Code: Total Pages: a 5
}

Key Words: materials, methods, results, electrochemical corrosion rates, pitting, coupon, temperature, ammonia, concentration, A515 carbon steel, 241-AY-101, simulant, testing coupon, electrochemical, software, $\mathrm{pH}$, safety, waste generation, equipment, cyclic potentiodynamic polarization, open circuit potential, ASTM G5-94, ASTM G61-86

Abstract: This report documents the results from RPP-PLAN-38676, Effect of Temperature and Ammonia Concentration on A515 Carbon Steel in Tank 241-AY-101 Simulant. The purpose of this test plan was to investigate the simulant formulated for the double-shell tank (DST) 241 AY 101 (AY 101) with the addition of ammonia. The simulant was formulated from the AY-101 condensate surface layer recipe used by CC Technologies $\circledast$ in the investigation of Hanford DST chemistry, under the Expert Panel on Corrosion. AY-101 is constructed from A515 grade 60 steel. The laboratory investigation used a cylindrical corrosion coupon from this steel formulation with a surface area of 5.64 square centimeters.

TRADEMARK DISCLAIMER. Reference herein to any specific commercial product, process, or service by trade name, trademark, manufacturer, or otherwise, does not necessarily constitute or imply its endorsement, recommendation, or favoring by the United States Government or any agency thereof or its contractors or subcontractors.

Printed in the United States of America. To obtain copies of this document, contact: Document Control Services, P.O. Box 950, Mailstop H6-08, Richland WA 99352, Phone (509) 372-2420; Fax (509) 376-4989.

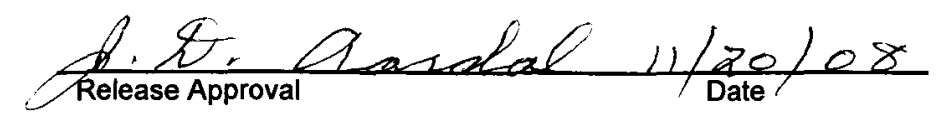

Approved For Public Release

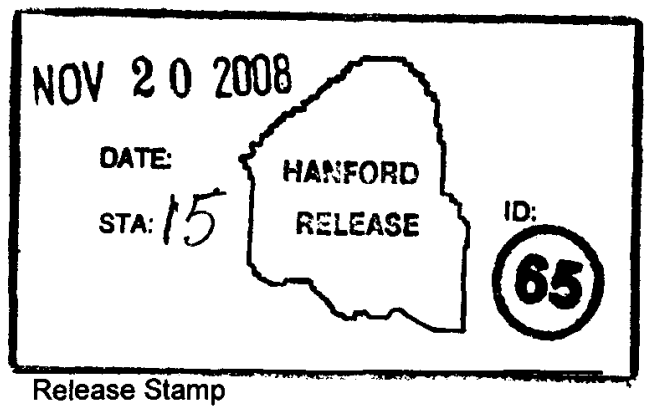




\section{Report on the Effect of Temperature and Ammonia Concentration on A515 Carbon Steel in Tank 241-AY-101 Simulant}

D. P. Frye

ANR Group, Inc.

J. B. Duncan

R. B. Wyrwas

Washington River Protection Solutions LLC

Date Published

November 2008

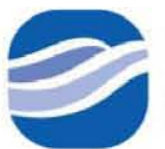

washington river

protectionsolutions

Prepared for the U.S. Department of Energy

Office of River Protection

Contract No. DE-AC27-08RV14800 


\section{Table of Contents}

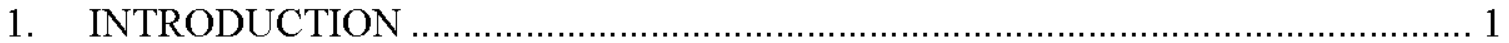

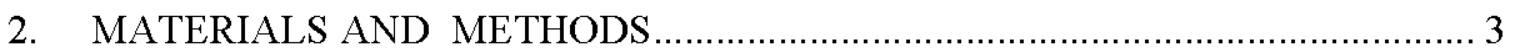

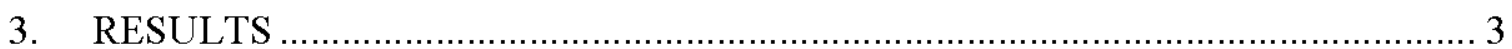

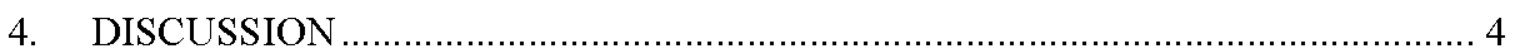

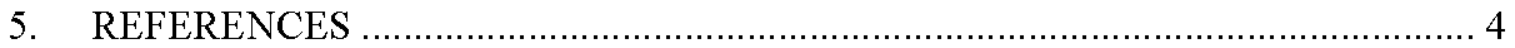

APPENDIX A Tank 241-AY-101 Simulant Formula …......................................... A-i

APPENDIX B American Society for Testing and Materials Scans ............................ B-i

APPENDIX C Cyclic Potentiometric Polarization Scans ....................................... C-i

APPENDIX D Photographs of Coupons from Scans ........................................... D-i

\section{List of Figures}

Figure 1. Cyclic Potentiodynamic Polarization Curve Showing Positive Hysteresis (Pitting).

\section{List of Tables}

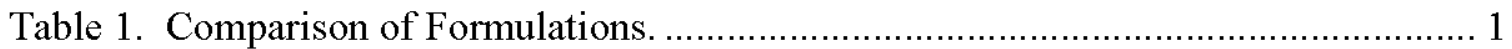

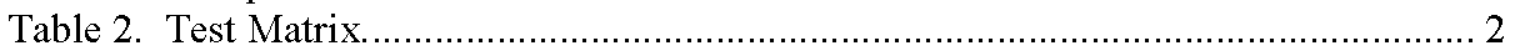

Table 3. Electrochemical Corrosion Rates and Pitting Propensity ................................. 4

\section{List of Terms}

\section{Abbreviations}

ASTM American Society for Testing and Materials

AY-101 241-AY-101

CCT CC Technologies ${ }^{\circledR}$

CPP cyclic potentiodynamic polarization

DST double-shell tank

EPOC Expert Panel on Corrosion

OCP open circuit potential

WRPS Washington River Protection Solutions LLC 


\section{INTRODUCTION}

This report documents the results from RPP-PLAN-38676, Effect of Temperature and Ammonia Concentration on A515 Carbon Steel in Tank 241-AY-101 Simulant. The purpose of this test plan was to investigate the simulant formulated for the double-shell tank (DST) 241-AY-101 (AY-101) with the addition of ammonia. The simulant was formulated from the AY-101 condensate surface layer recipe (Appendix A) used by CC Technologies ${ }^{\circledR 1}$ (CCT) in the investigation of Hanford DST chemistry, under the Expert Panel on Corrosion (EPOC). Table 1 shows the comparison of the CCT simulant, the simulant formulated in the 222-SA cold laboratory, and the difference after ammonia was added.

Table 1. Comparison of Formulations.

\begin{tabular}{|l|c|c|c|}
\hline \multicolumn{1}{|c|}{ Reagent } & $\begin{array}{c}\text { CCT } \\
\text { Formulation } \\
\text { Molarity }\end{array}$ & $\begin{array}{c}\text { WRPS } \\
\text { Formulation } \\
\text { Molarity }\end{array}$ & $\begin{array}{c}\text { WRPS Formulation } \\
\text { with Ammonia } \\
\text { Molarity }\end{array}$ \\
\hline Sodium aluminate $\left(\mathrm{NaAlO}_{2} \cdot 2 \mathrm{H}_{2} \mathrm{O}\right)$ & 0.0153 & 0.0153 & 0.0153 \\
\hline Sodium chloride $(\mathrm{NaCl})$ & 0.0064 & 0.0064 & 0.0064 \\
\hline Sodium fluoride $(\mathrm{NaF})$ & 0.0015 & 0.0015 & 0.0015 \\
\hline Sodium chromate $\left(\mathrm{Na}_{2} \mathrm{CrO}_{4} \cdot 4 \mathrm{H}_{2} \mathrm{O}\right)$ & 0.0003 & 0.0003 & 0.0003 \\
\hline Sodium sulfate $\left(\mathrm{Na}_{2} \mathrm{SO}_{4}\right)$ & 0.0021 & 0.0021 & 0.0021 \\
\hline Sodium phosphate $\left(\mathrm{Na}_{3} \mathrm{PO}_{4} \cdot 12 \mathrm{H}_{2} \mathrm{O}\right)$ & 0.0059 & 0.0059 & 0.0059 \\
\hline Sodium oxalate $\left(\mathrm{Na}_{2} \mathrm{C}_{2} \mathrm{O}_{4}\right)$ & 0.0014 & 0.0014 & 0.0014 \\
\hline Sodium carbonate $\left(\mathrm{Na}_{2} \mathrm{CO}_{3}\right)$ & 0.1474 & 0.1474 & 0.1474 \\
\hline Sodium nitrate $\left(\mathrm{NaNO}_{3}\right)$ & 0.1810 & 0.1810 & 0.476 \\
\hline Sodium nitrite $\left(\mathrm{NaNO}_{2}\right)$ & 0.0368 & 0.0368 & 0.0368 \\
\hline Sodium hydroxide $(\mathrm{NaOH})$ & 0.0050 & 0.0050 & 0.0050 \\
\hline Sodium & 0.5546 & 0.5546 & 0.5546 \\
\hline Ammonium nitrate $\left(\mathrm{NH}_{4} \mathrm{NO}_{3}\right)$ & NA & NA & 0.295 \\
\hline pH & Adjusted & Adjusted & Adjusted \\
\hline $\begin{array}{l}\text { CCT }=\text { CC Technologies } \\
\text { WRPS }=\text { Washington River Protection Solutions LLC }\end{array}$
\end{tabular}

The AY-101 is constructed from A515 grade 60 steel. The laboratory investigation used a cylindrical corrosion coupon from this steel formulation with a surface area of $5.64 \mathrm{~cm}^{2}$. Table 2 shows the simulant test matrix.

It is beyond the scope of this effort to establish a breakpoint for ammonia passivation by titrating specified concentrations. Rather, this effort was to establish whether or not ammonia had a passivating influence on the gross pitting propensity as reported in the Biweekly Status Reports provided by the ARES Corporation program manager for the EPOC Hanford DST waste simulant chemistry effects on DST steel.

\footnotetext{
${ }^{1} \mathrm{CC}$ Technologies ${ }^{\circledR}$ is a registered trademark of Cortest Columbus Technologies, Dublin, Ohio.
} 
RPP-RPT-39307, Rev. 0

Table 2. Test Matrix.

\begin{tabular}{|c|c|c|c|c|}
\hline Simulant & Coupon & pH & Temperature & $\mathrm{NH}_{4} \mathrm{NO}_{3}$ \\
\hline \multirow{3}{*}{$1 \mathrm{AY}$} & \multirow{3}{*}{ A 515} & \multirow{3}{*}{11.8} & \multirow[t]{2}{*}{$50^{\circ} \mathrm{C}$} & + \\
\hline & & & & - \\
\hline & & & Ambient & $\begin{array}{l}\text { Not conducted } \\
\text { Figure C-6 }\end{array}$ \\
\hline \multirow{3}{*}{$1 \mathrm{AY}$} & \multirow{3}{*}{ A515 } & \multirow{3}{*}{12.8} & \multirow[t]{2}{*}{$50^{\circ} \mathrm{C}$} & + \\
\hline & & & & - \\
\hline & & & Ambient & $\begin{array}{l}\text { Not conducted } \\
\text { Figure C-3 }\end{array}$ \\
\hline
\end{tabular}

From the laboratory effort at CCT, the corrosion coupon exhibited pitting at both $\mathrm{pH} 11.8$ and $\mathrm{pH} 12.8$ when scanned at $50^{\circ} \mathrm{C}$ (Figure 1).

To determine the pitting potential of the type A515 carbon steel in the $1 \mathrm{AY}$ simulant, cyclic potentiodynamic polarization (CPP) scans were performed on the coupon under the conditions described in Table 1. After a 1-hour equilibration period, the CPP scans were initiated $-200 \mathrm{mV}$ below open circuit potential (OCP) and reversed when the current density reached $2.5 \mathrm{~mA} / \mathrm{cm}^{2}$ [American Society for Testing and Materials (ASTM) G61-86, Standard Test Method for Conducting Cyclic Potentiodynamic Polarization Measurements for Localized Corrosion Susceptibility of Iron-, Mckel-, or Cobalt-Based Alloys]. The electrochemical corrosion rates were obtained using the embedded algorithm in the EC-Lab ${ }^{\text {(2) }}$ instrument controlling sof tware. The algorithm uses the equation by Stern and Geary to obtain the corrosion current and calculate the corrosion rate (Stern and Geary 1957).

Figure 1. Cyclic Potentiodynamic Polarization Curve Showing Positive Hyster esis (Pitting).

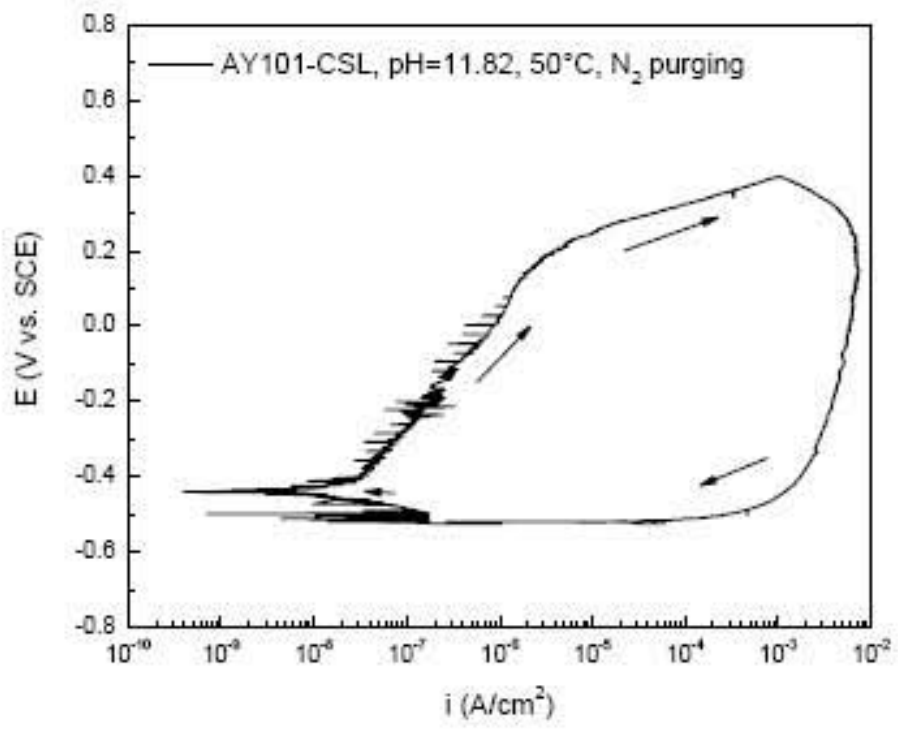

${ }^{2}$ EC-L ab is a registered tradem ark of Bio-Logic SAS, Claix, France. 


\section{MATERIALS AND METHODS}

The metal coupons used in this study were obtained from Metal Samples ${ }^{\circledR 3}$ and were type A515 grade 60 carbon steel. The coupons were cylindrical with a surface area of approximately $5.64 \mathrm{~cm}^{2}$. All coupons were wet-sanded with 600 -grit waterproof sandpaper and cleaned ultrasonically for 2 minutes before being affixed to a 316 stainless steel electrode mounting rod.

ASTM G5-94, Standard Reference Test Method for Making Potentiostatic and Potentiodynamic Anodic Polarization Measurements, was used as an instrument check before and after electrochemical testing to ensure that the potentiostat was functioning properly. The ASTM G5-94 method is a one-way potentiodynamic scan using a 430 stainless steel coupon. For all scans, a saturated calomel electrode was used as the reference electrode.

The source of ammonia was ammonium nitrate. Approximately $2.36 \mathrm{~g}$ of ammonium nitrate was added per $100 \mathrm{~mL}$ of simulant. This resulted in a calculated ammonia concentration of approximately $0.3 \mathrm{M}$. Scan rates were $0.16 \mathrm{mV} / \mathrm{sec}$ for the ASTM potentiodynamic and nonammonia scans. For the scans where ammonia was added, the scan rate was $1.6 \mathrm{mV} / \mathrm{sec}$. The reason for the increase in scan rate was to maximize the ammonia-coupon exposure. Ammonia will volatilize over the 3 - to 4 -hour period that the slower scan rate requires.

The potentiostat used is a VMP2 $2^{\circledR 4}$ multipotentiostat manufactured by Bio-Logic. The VMP2 ${ }^{\circledR}$ potentiostat uses instrument controlling and analyses software EC-Lab ${ }^{\circledR}$ version 9.45.

All of the scans conducted without the presence of ammonia-producing compounds were conducted at a scan rate of $0.166-\mathrm{mV} / \mathrm{s}$. Those conducted in the presence of either the $\mathrm{NH}_{4} \mathrm{NO}_{3}$ or the $\mathrm{NH}_{4} \mathrm{OH}$ were conducted at a scan rate of $1.6 \mathrm{mV} / \mathrm{s}$ to compensate for the loss of gaseous ammonia from the system.

For tests with the ammonia producing compound, the ASTM cell was used rather than the usual 500-mL I-CHEM. ${ }^{5}$ A reflux column was used to minimize the loss of ammonia in the headspace, which would reduce the ammonia concentration in the simulant through equilibrium processes.

\section{RESULTS}

Results of the ASTM G5-94 scans are presented in Appendix B.

The CPP scans of the A515 coupon against the AY-101 simulant are presented in Appendix C. Scans for which an electrochemical corrosion rate could be calculated are presented in Table 3.

The coupons associated with the scans in Table 3 are presented in Appendix D.

\footnotetext{
${ }^{3}$ Metal Samples is a division of Alabama Specialty Products, Inc., Munford, Alabama.

${ }^{4}$ VMP2 is a registered trademark of Bio-Logic SAS, Claix, France.

${ }^{5}$ I-CHEM Certified is a registered trademark of I-CHEM Acquisition Co. Corporation, New Castle, Delaware.
} 
Table 3. Electrochemical Corrosion Rates and Pitting Propensity.

\begin{tabular}{|c|c|c|c|c|c|c|}
\hline $\begin{array}{c}\mathrm{pH} \\
\text { (Temperature) }\end{array}$ & $\mathrm{NH}_{3}$ & $\begin{array}{c}\begin{array}{c}\text { Electrochemical } \\
\text { Corrosion Rate } \\
\text { (mpy) }\end{array} \\
\end{array}$ & $\begin{array}{r}\text { OCP } \\
(\mathrm{mV}) \\
\end{array}$ & $\begin{array}{c}\chi^{2} \\
\text { Statistic }\end{array}$ & $\begin{array}{c}\text { Hysteresis } \\
\text { ( += pitting } \\
-=\text { no pitting) }\end{array}$ & Appendix C \\
\hline $12.8\left(50^{\circ} \mathrm{C}\right)$ & No & $1.2 \mathrm{E}-02$ & -502 & 0.68 & + & C-1 \\
\hline $12.8\left(50^{\circ} \mathrm{C}\right)$ & Yes & Noise* & -257 & $\mathrm{NA}$ & - & $\mathrm{C}-2$ \\
\hline 12.8 (ambient) & No & $6.9 \mathrm{E}-03$ & -456 & 0.41 & - & $\mathrm{C}-3$ \\
\hline $11.8\left(50^{\circ} \mathrm{C}\right)$ & No & $1.02 \mathrm{E}-02$ & -562 & 0.50 & + & $\mathrm{C}-4$ \\
\hline $11.8\left(50^{\circ} \mathrm{C}\right)$ & Yes & Noise & -391 & NA & - & C-5 \\
\hline 11.8 (ambient) & No & $2.8 \mathrm{E}-02$ & -411 & 2.4 & - & C-6 \\
\hline
\end{tabular}

* The algorithm would not calculate a corrosion rate; the $i_{\text {corr }}$ was established manually.

\section{DISCUSSION}

From the laboratory experiments, temperature has a profound effect on the electrochemical corrosion of the coupon. This is evidenced by the pitting propensity of both the $\mathrm{pH} 11.8$ and the $\mathrm{pH} 12.8$ as shown in the CPP scans at $50{ }^{\circ} \mathrm{C}$, as well as ambient temperature showing negative hysteresis at the same $\mathrm{pH}$ levels.

It is also evident that ammonia has a passivating influence at the higher temperatures. What is not immediately obvious is the mechanism that is involved. There is a definite effect on the coupon, possibly at the double layer, that is evident at the OCP. Possibly the ammonia is engaging in a chemical reaction. Until further investigation can be carried out, only speculation can occur. However, the OCP variation does provide a clue as to where to begin an in-depth study.

\section{REFERENCES}

ARES Biweekly Status Report, June 27, 2008, Client PO CCT 0603114.24-001, Project 8117013 , ARES Corporation, Richland, Washington.

ASTM G5-94, 1999 (Reapproved 1999), Standard Reference Test Method for Making Potentiostatic and Potentiodynamic Anodic Polarization Measurements, American Society for Testing and Materials, West Conshohocken, Pennsylvania.

ASTM G61-86, 2003 (Reapproved 2003), Standard Test Method for Conducting Cyclic Potentiodynamic Polarization Measurements for Localized Corrosion Susceptibility of Iron-, Nickel-, or Cobalt-Based Alloys, American Society for Testing and Materials, West Conshohocken, Pennsylvania. 
RPP-RPT-39307, Rev. 0

RPP-PLAN-38676, 2008, Effect of Temperature and Ammonia Concentration on A515 Carbon Steel in Tank 241-AY-101 Simulant, Rev. 0, CH2M HILL Hanford Group, Inc., Richland, Washington.

Stern, M., and A. L. Geary, 1957, "The Shape of Electrochemical Polarization Curves," J. Electrochem. Soc., 104, 56. 
RPP-RPT-39307, Rev. 0

\section{APPENDIX A}

\section{Tank 241-AY-101 Simulant Formula}


AY101-CSL adapted from CC Technologies ${ }^{\circledR}$

Base Solution 2008 Version
Batch size: $1 \mathrm{~L}$

pH: 11.82

Balance Device ID:

NIST weight (

Balance Device ID: NIST weight (

g):

g):

Technician:

Date:

Add:

600-mL deionized water (DI) to a beaker,

Insert Teflon ${ }^{\circledR 1}$ stirbar and thermocouple/thermometer and place on stir/hot plate.

Turn on heater and adjust to $60^{\circ} \mathrm{C}\left( \pm 10^{\circ} \mathrm{C}\right)$.

Add the following chemicals and record their actual weights:

\begin{tabular}{|l|l|c|c|c|}
\hline \multicolumn{1}{|c|}{ Chemical } & \multicolumn{1}{|c|}{ Formula } & \multicolumn{1}{c|}{$\begin{array}{c}\text { Required } \\
\text { mass (g) }\end{array}$} & $\begin{array}{c}\text { Actual mass } \\
\text { (g) }\end{array}$ & Comments \\
\hline Sodium Aluminate & $\mathrm{NaAlO}_{2} \cdot 2 \mathrm{H}_{2} \mathrm{O}$ & 1.81 & & \\
\hline Sodium Chloride & $\mathrm{NaCl}$ & 0.37 & & \\
\hline Sodium Fluoride & $\mathrm{NaF}$ & 0.06 & & \\
\hline Sodium Chromate & $\mathrm{Na}_{2} \mathrm{CrO}_{4} \cdot 4 \mathrm{H}_{2} \mathrm{O}$ & 0.07 & & \\
\hline Sodium Sulfate & $\mathrm{Na}_{2} \mathrm{SO}_{4}$ & 0.30 & & \\
\hline $\begin{array}{l}\text { Sodium Phosphate, } \\
\text { 12-Hydrate }\end{array}$ & $\mathrm{Na}_{3} \mathrm{PO}_{4} \cdot 12 \mathrm{H}_{2} \mathrm{O}$ & 2.24 & & \\
\hline Sodium Oxalate & $\mathrm{Na}_{2} \mathrm{C}_{2} \mathrm{O}_{4}$ & 0.19 & & \\
\hline Sodium Carbonate & $\mathrm{Na}_{2} \mathrm{CO}_{3}$ & 15.62 & & \\
\hline Sodium Nitrate & $\mathrm{NaNO}_{3}$ & 15.38 & & \\
\hline Sodium Nitrite & $\mathrm{NaNO}_{2}$ & 2.54 & & \\
\hline Sodium Hydroxide & $\mathrm{NaOH}$ & 0.20 & & \\
\hline
\end{tabular}

* Sodium Fluoride is very toxic, handle with care.

Adjust total solution volume to $850-\mathrm{mL}$ with DI water.

Adjust solution temperature to $50^{\circ} \mathrm{C}$ to $60^{\circ} \mathrm{C}$.

Filter solution by vacuum through medium glass filter. Warning solution hot and caustic.

Rinse beaker with approximately $50 \mathrm{~mL}$ of DI water.

Rinse filter with approximately $50 \mathrm{~mL}$ of DI water.

Transfer final filtrate and rinse solutions to large beaker with stirbar.

Transfer to $1 \mathrm{~L}$ volumetric flask and include rinse with DI water. Let solution cool.

Adjust final volume to $1 \mathrm{~L}$, and mix well.

SUM: $\quad$ Total chemicals (target): $38.79 \mathrm{~g}$

Total water (target): $1 \mathrm{~L}$

Target specific density: 1.04

(actual):

(actual):

(actual):

Check final solution $\mathrm{pH}$ and record.

$\mathrm{pH}: \_$Readjust if far from target.

Comments:

${ }^{1}$ Teflon $^{\circledR}$ is a registered trademark of I. E. du Pont de Nemours and Company, Wilmington, Delaware. 
RPP-RPT-39307, Rev. 0

APPENDIX B

American Society for Testing and Materials Scans 
RPP-RPT-39307, Rev. 0

Figure B-1. ASTM Scans Overlay.

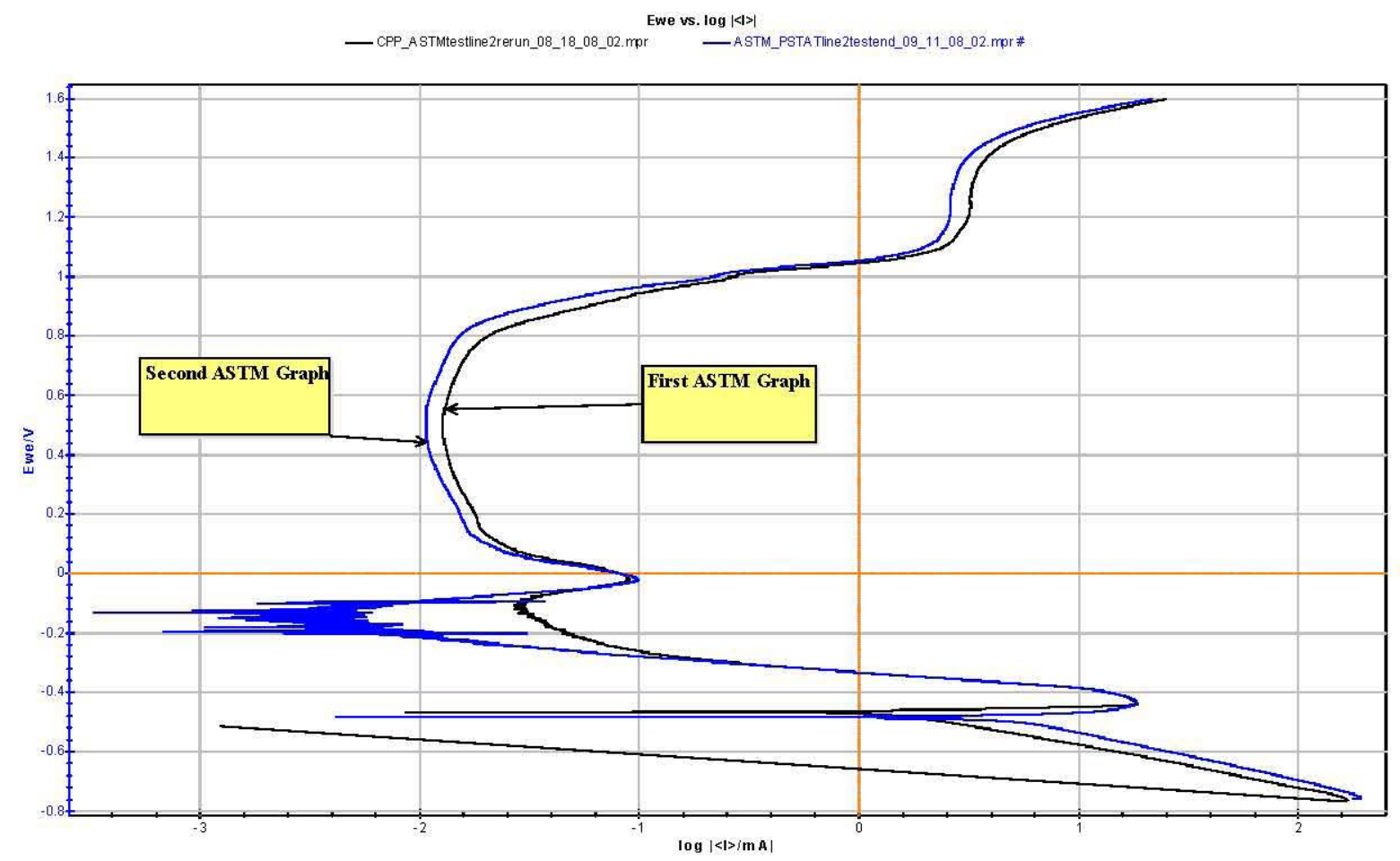


RPP-RPT-39307, Rev. 0

\section{APPENDIX C}

Cyclic Potentiodynamic Polarization Scans 
RPP-RPT-39307, Rev. 0

Figure C-1. Cyclic Potentiodynamic Polarization Scan without Ammonia Present, $\mathrm{pH} 12.8,50^{\circ} \mathrm{C}$.

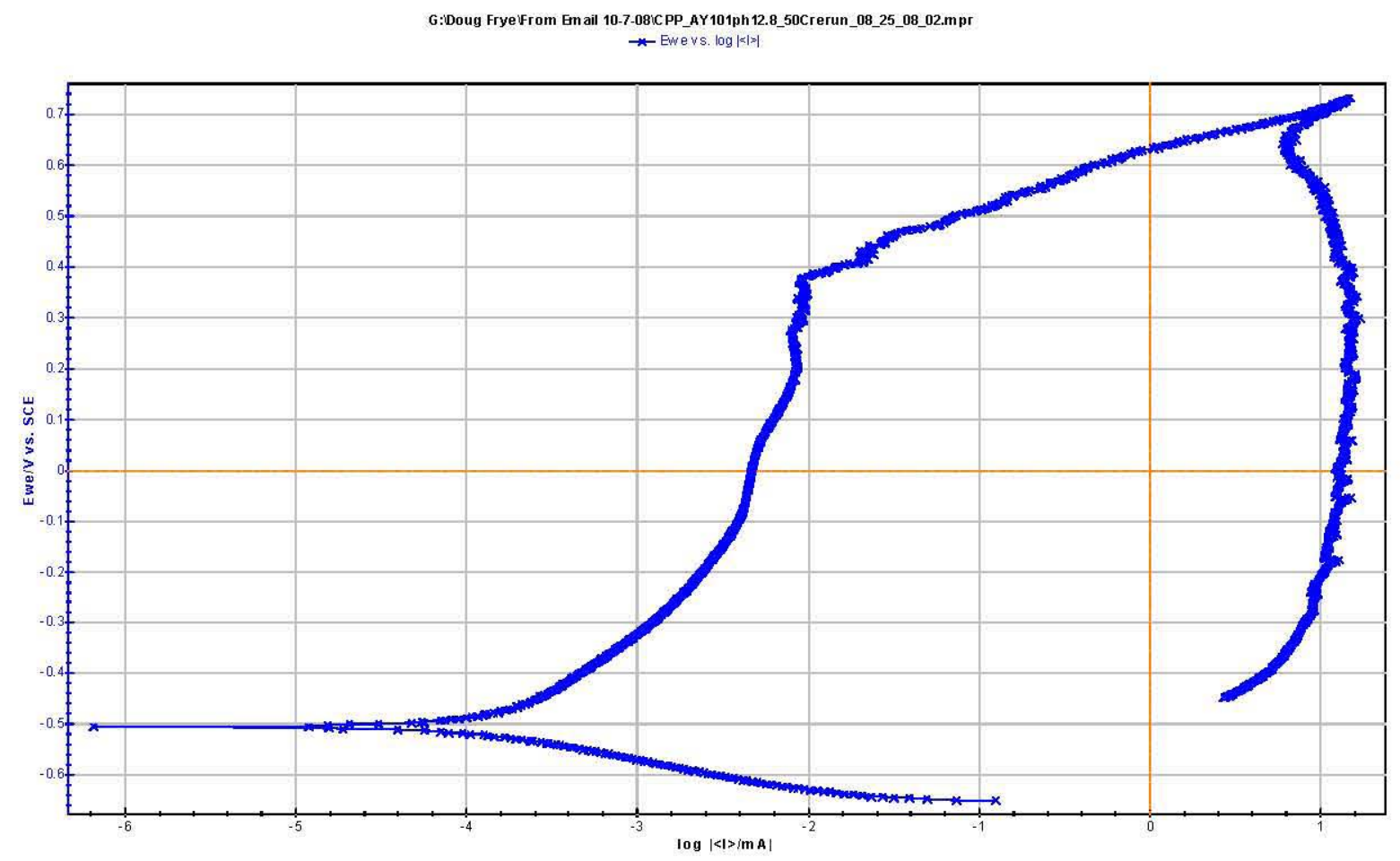


Figure C-2. Cyclic Potentiodynamic Polarization Scan with Ammonia Present, $\mathrm{pH} 12.8,50{ }^{\circ} \mathrm{C}$.

G:Doug FryelFrom Email 10-7-08iCPP_AY101_ph 12.8+NH4NO350C_09_11_08_02.mpr * Ewevs. $\log |<| \geqslant \mid$

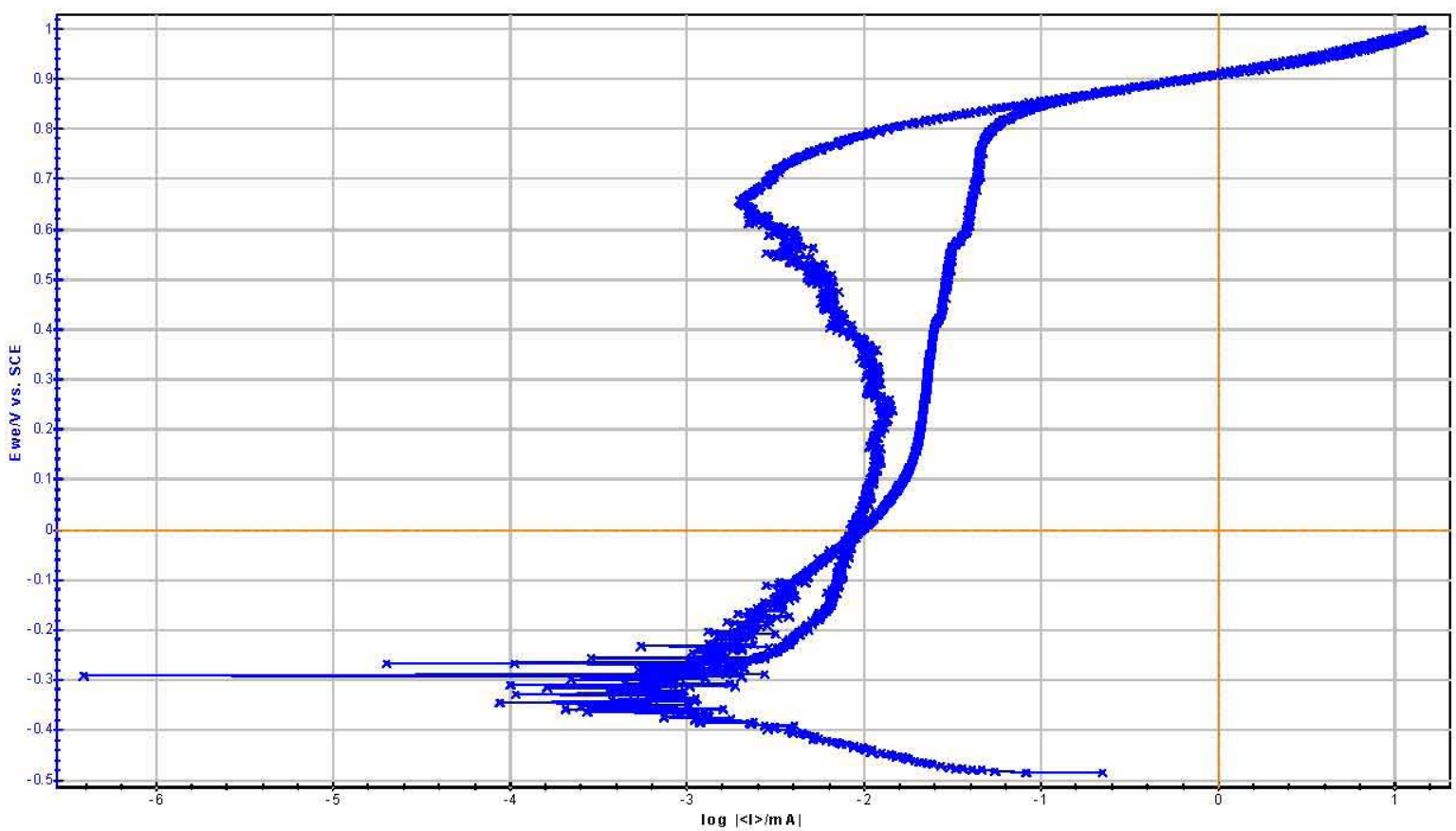


Figure C-3. Cyclic Potentiodynamic Polarization Scan without Ammonia Present, pH 12.8, Ambient Temperature.

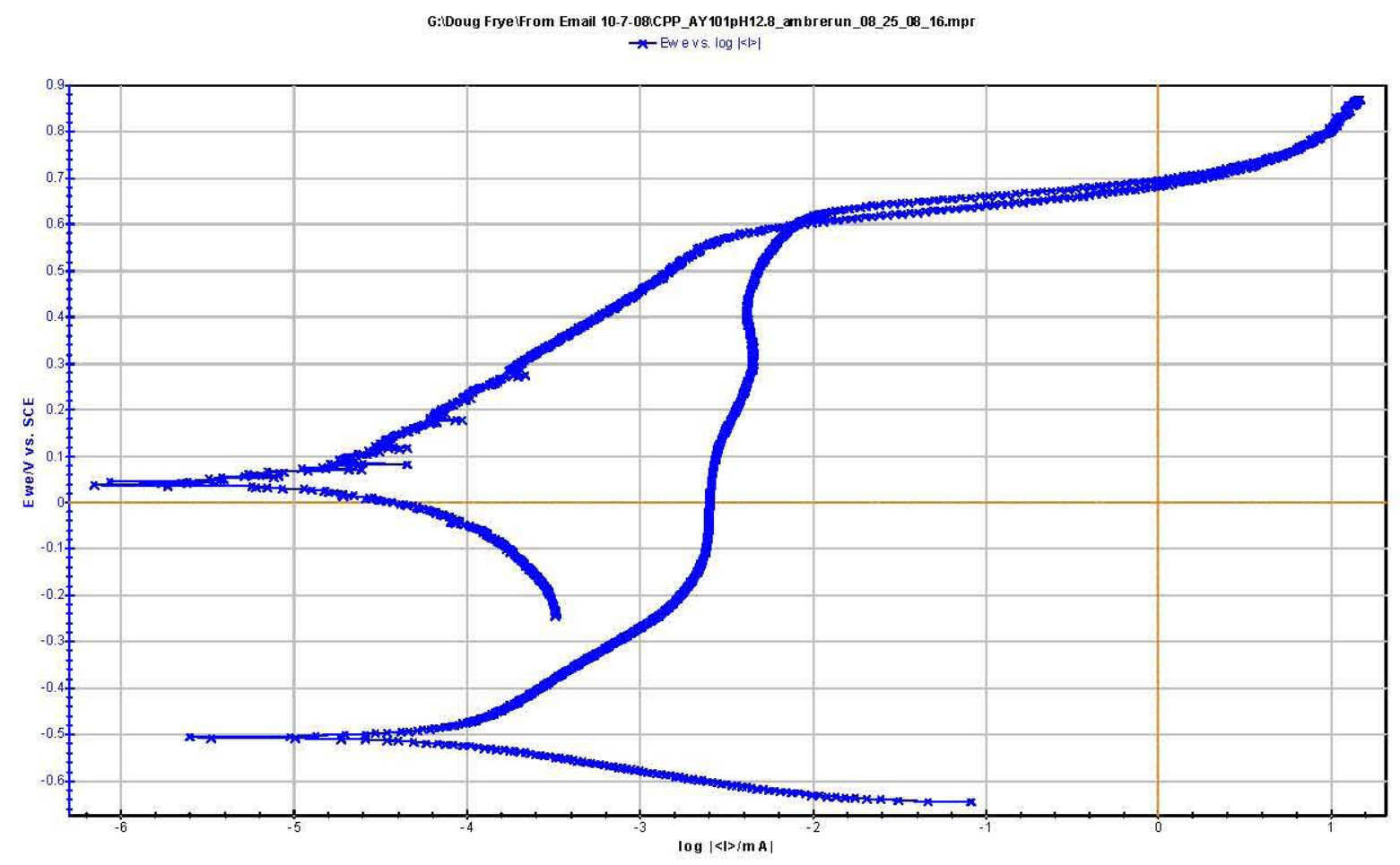


RPP-RPT-39307, Rev. 0

Figure C-4. Cyclic Potentiodynamic Polarization Scan without Ammonia Present, $\mathrm{pH} 11.8,50^{\circ} \mathrm{C}$.

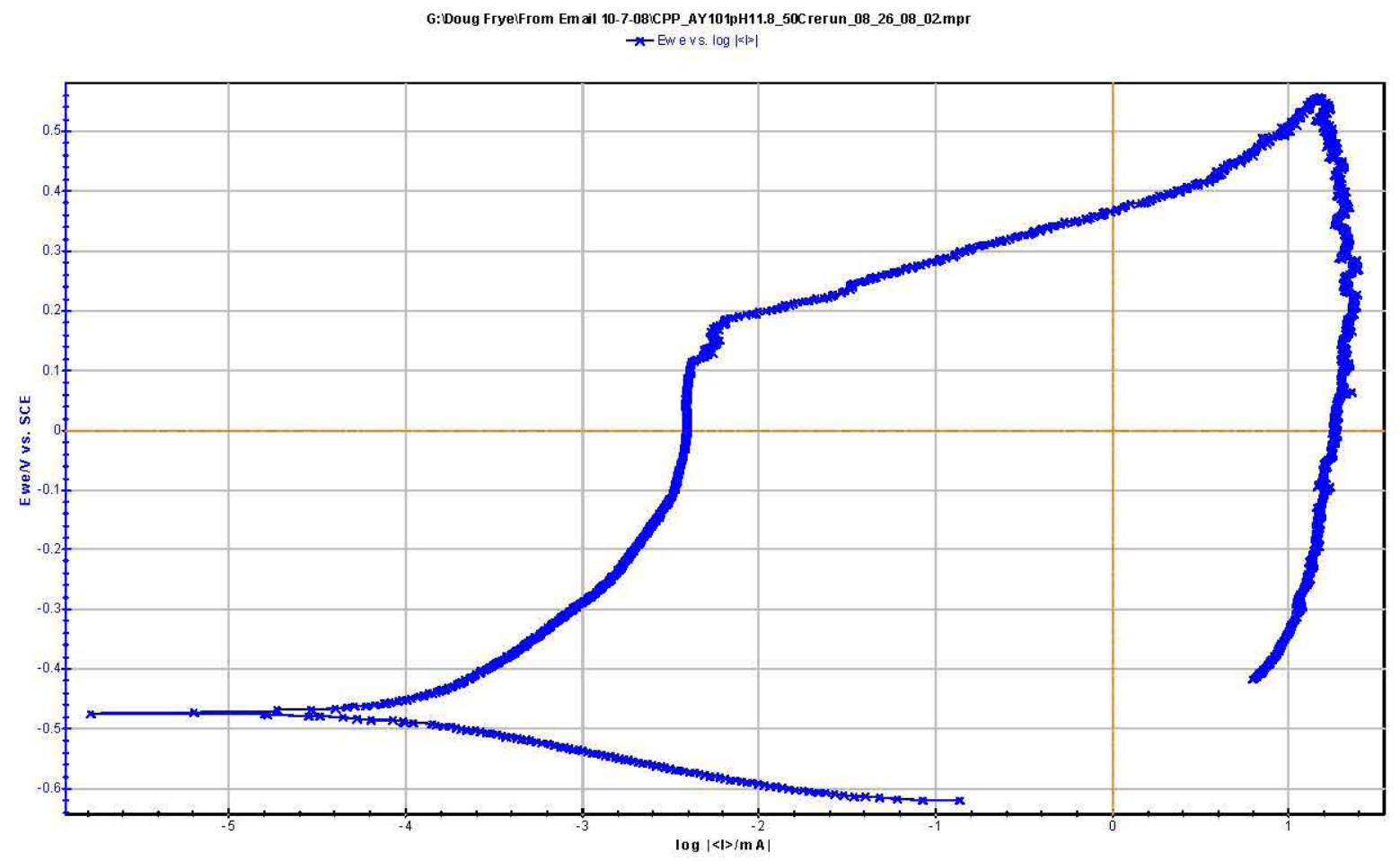


Figure C-5. Cyclic Potentiodynamic Polarization Scan with Ammonia Present, pH 11.8, $50^{\circ} \mathrm{C}$.

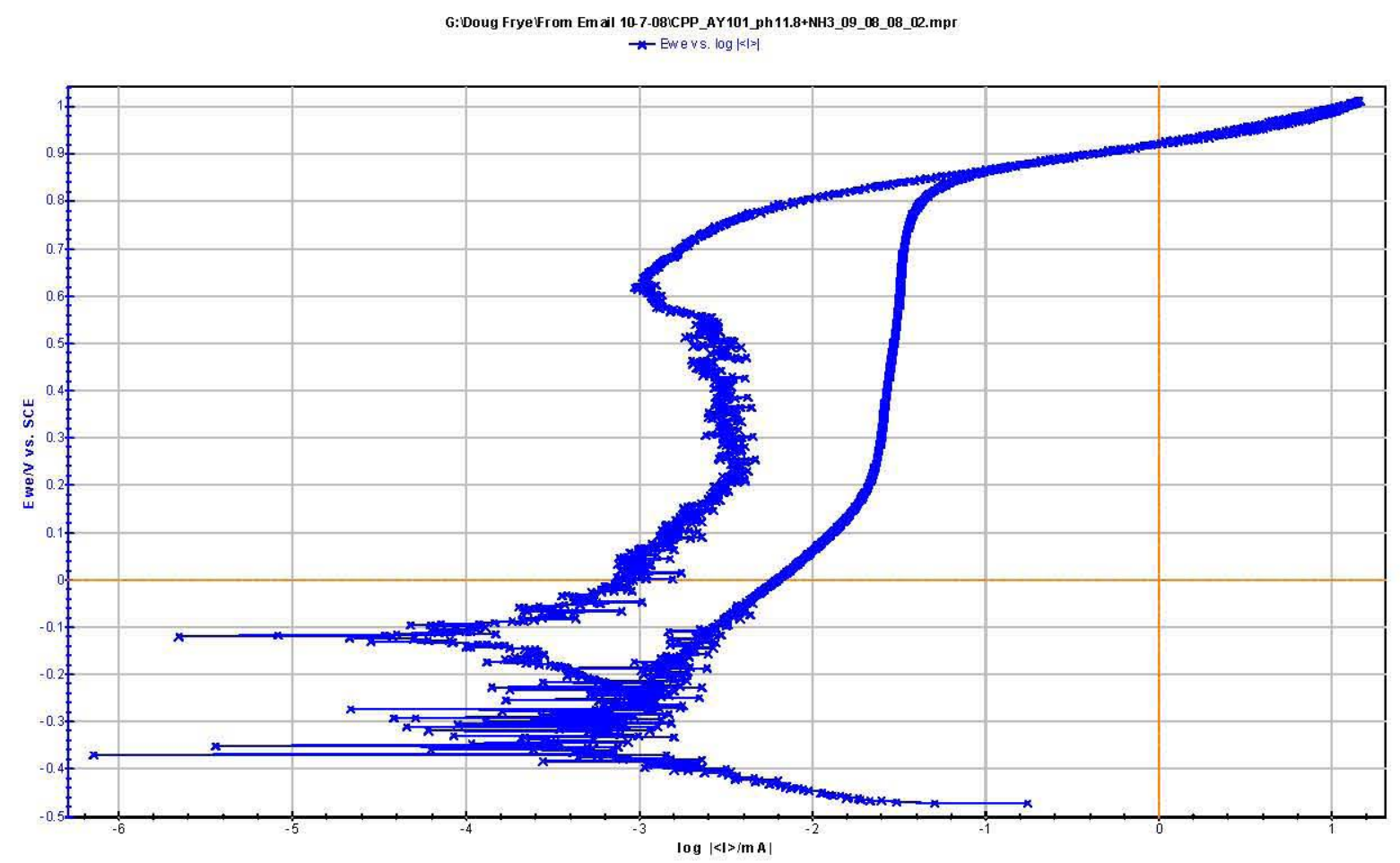


Figure C-6. Cyclic Potentiodynamic Polarization Scan without Ammonia Present, pH 11.8, Ambient Temperature.

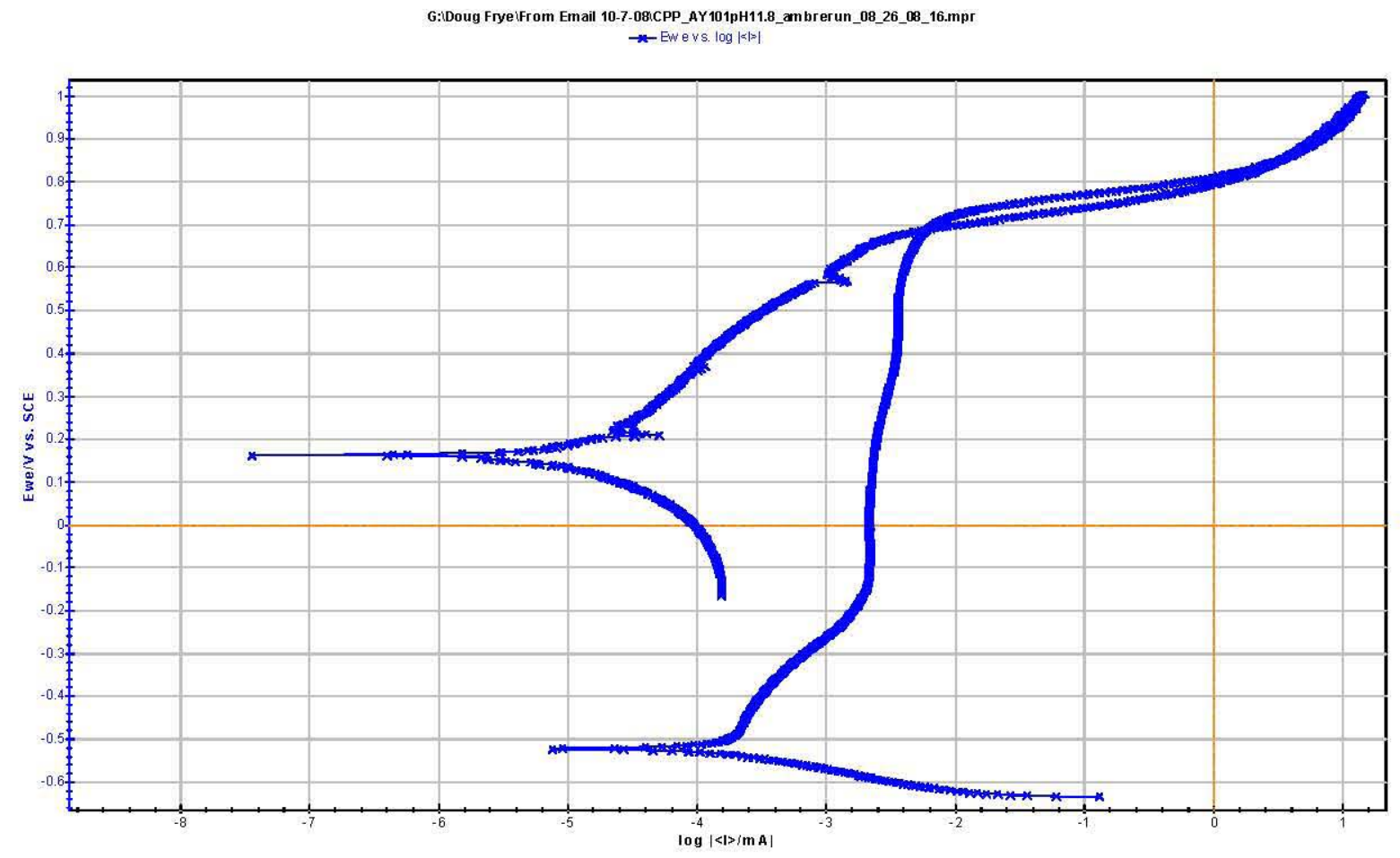


RPP-RPT-39307, Rev. 0

\section{APPENDIX D}

Photographs of Coupons from Scans 
RPP-RPT-39307, Rev. 0

Figure D-1. Coupon, pH 12.8, $50{ }^{\circ} \mathrm{C}$, No Ammonia Present.

Figure D-2. Coupon, pH 12.8, $50{ }^{\circ} \mathrm{C}$, Ammonia Present. 
RPP-RPT-39307, Rev. 0

Figure D-3. Coupon, pH 12.8, Ambient, No Ammonia Present.

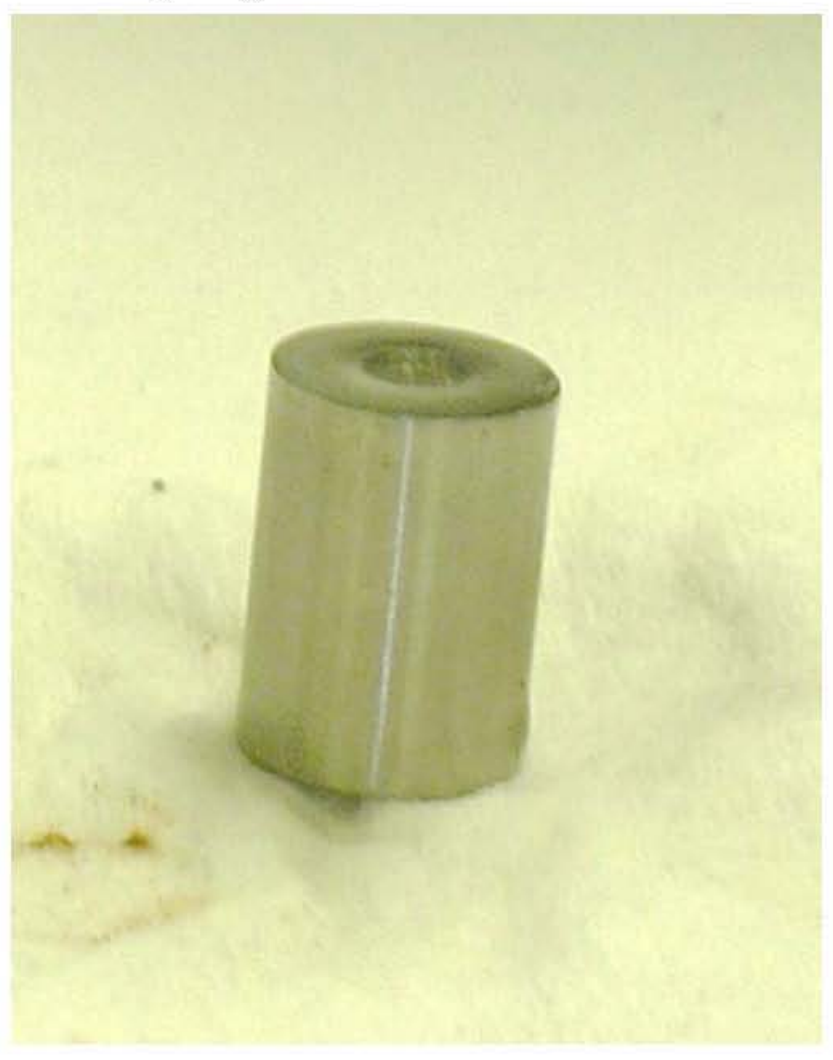

Figure D-4. Coupon, pH 11.8, $50{ }^{\circ} \mathrm{C}$, No Ammonia Present. 


$$
\text { RPP-RPT-39307, Rev. } 0
$$

Figure D-5. Coupon, $\mathrm{pH} 11.8,50^{\circ} \mathrm{C}$, Ammonia Present.

Figure D-6. Coupon, pH 11.8, Ambient Temperature, No Ammonia Present.

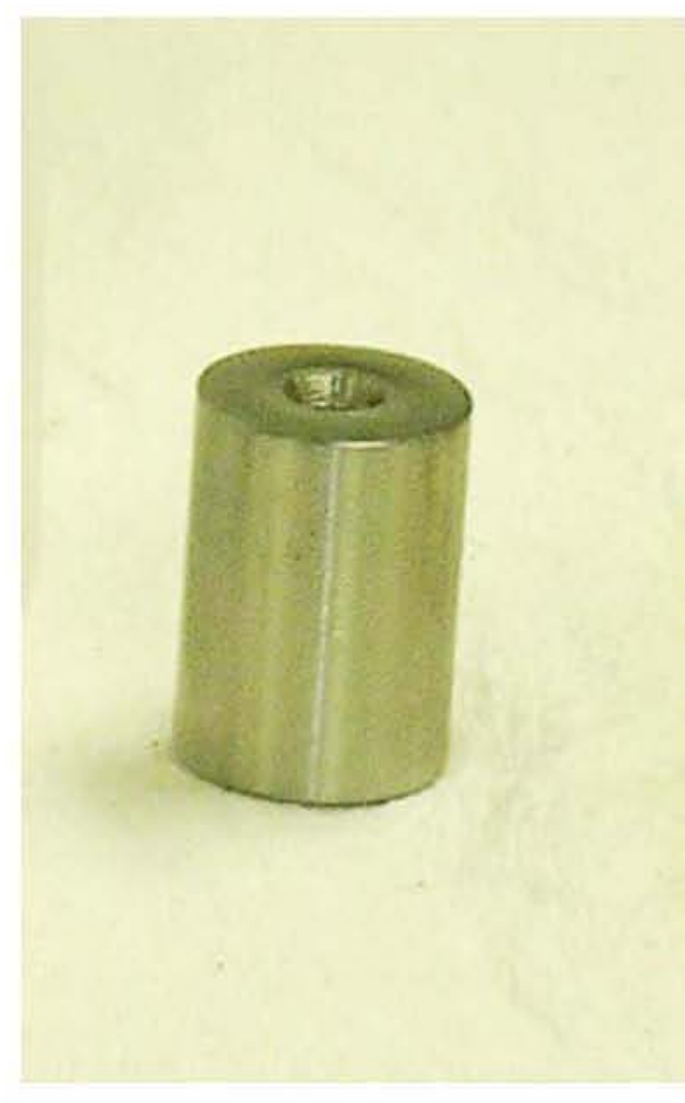

